\title{
MEMBANGUN APLIKASI KELUAR MASUK BARANG VAKSIN PADA PT. DHARMA BANDAR MANDALA
}

\author{
Aripan Setiapani ${ }^{1}$, Dwi Marlina ${ }^{2}$ \\ ${ }^{1,2}$ Teknik Informatika, Fakultas Teknik dan Ilmu Komputer, Universitas Indraprasta PGRI Jakarta \\ Jalan Raya Tengah No 80, Kelurahan Gedong, Pasar Rebo, Jakarta Timur \\ 12aripansetiapani@gmail.com, 22dhuwie.marlina@gmail.com
}

\begin{abstract}
ABSTRAK
Permasalahan pada PT. Dharma Bandar Mandala adalah sistem yang berjalan pada jasa angkutan kargo tersebut menggunakan cara serah terima barang secara manual atau menggunakan tulisan di buku dan menerima orderan melalui $e$-mail kemudian pada saat pengelolaan data keluar masuk barang vaksin di PT Dharma Bandar Mandala sering terjadi kesalahan pencatatan, dan pelaporan. Tujuan merancang suatu aplikasi keluar masuk barang vaksin untuk memudahkan admin dalam memproses pengolahan data yang ada saat ini. Perangkat aplikasi yang telah dibuat dengan bahasa pemrograman Java NetBeans 8.0.2 dan penyimpanan data pada database MySQL dapat memberikan kelancaran dalam proses menginput dan penyimpanan data-data serta laporan-laporan yang diberikan kepada pimpinan perusahaan. Metode penelitian yang digunakan adalah metode kualitatif, dengan metode ini dapat menyelesaikan permasalahan yang ada di PT. Dharma Bandar Mandala. Hasil dari penelitian ini menciptakan suatu sistem pengolahan data keluar masuk barang vaksin sebagai fasilitas yang dapat membantu proses keluar masuk barang vaksin dan pencarian data lebih baik dan akurat.
\end{abstract}

Kata Kunci: Aplikasi, Keluar, Masuk, Vaksin, Desktop

\begin{abstract}
Problems at PT. Dharma Bandar Mandala is a system that runs on the cargo transportation service using the manual handover of goods or using writing in a book and receiving orders via e-mail then when managing data in and out of vaccine goods at PT Dharma Bandar Mandala there are often recording errors, and reporting. The purpose of designing an application in and out of vaccine goods is to make it easier for admins to process the current data processing. Application tools that have been created using the Java NetBeans 8.0.2 programming language and data storage in the MySQL database can provide smooth processing of input and storage of data and reports provided to company leaders. The research method used is a qualitative method, with this method can solve the problems that exist in PT. Dharma Bandar Mandala. The results of this study create a data processing system in and out of vaccine goods as a facility that can help the process of entering and exiting vaccines and searching for better and more accurate data.
\end{abstract}

Key Word: Application, Exit, Enter, Vaccacine, Desktop

\section{PENDAHULUAN}

Saat ini banyak sekali perusahaan yang semakin peka terhadap kemajuan di bidang teknologi dan informasi yang dapat kita lihat baik itu perusahaan yang sudah besar bahkan kegiatan bisnis yang lingkupnya kecil sekalipun sudah terintegrasi dengan komputer (Rustamin \& Dewi, 2016). Dalam menjalankan kegiatan bisnis diperlukan teknologi untuk membantu proses bisnis yang berlangsung salah satunya adalah sistem persediaan barang. Persediaan barang adalah barang-barang yang disimpan untuk digunakan ataupun dijual kembali di dalam suatu perusahaan (Mahmudah, Widiastuti, \& Ernawati, 2019).
PT Dharma Bandar Mandala adalah Perusahaan jasa angkutan kargo yang menyediakan jasa kargo darat, laut, dan udara. Sistem yang berjalan pada jasa angkutan kargo tersebut menggunakan cara serah terima barang secara manual atau menggunakan tulisan di buku dan menerima orderan melalui e-mail. PT Dharma Bandar Mandala berdiri pada 27 Januari 1999 di Jakarta Indonesia, memulai bisnis dengan menjadi agen tunggal jasa (GSA) kargo untuk Mandala Airlines. Kerjasama ini berlangsung kurang lebih dua belas tahun dan harus berakhir pada tahun 2011. 
Kemudian PT Dharma Bandar Mandala beralih ke jasa distribusi vaksin dan merupakan salah satu perusahaan yang dipercaya pemerintah untuk menyuplai dan mendistribusikan vaksin untuk diberikan kepada mitra-mitra diseluruh Indonesia (Waluyo, Hanafri, \& Sulaeman, 2019). Dalam proses keluar masuk persediaan vaksin sering terjadi banyak kendala yang dialami karena proses pencatatan vaksin masuk dan vaksin keluar yang masih mempergunakan kertas sebagai bahan untuk pencatatannya sehingga data banyak yang terduplikasi dan menjadikan proses pencarian data serta pembuatan laporan membutuhkan waktu yang cukup lama (Maulana Syaban \& Bunyamin, 2016).

Dengan permasalahan tersebut, perlu ada nya suatu sistem yang terkomputerisasi dalam penyelesaiannya. Sistem adalah sekelompok unsur yang erat hubungannya satu dengan yang lain, yang berfungsi bersama-sama untuk mencapai tujuan (Sutabri, 2012). Sistem merupakan suatu kumpulan dari komponenkomponen yang membentuk satu kesatuan (Tyoso, 2016). Pembangunan sistem adalah sekumpulan aktivitas yang menggambarkan secara rinci bagaimana sistem akan berjalan. Hal itu bertujuan untuk menghasilkan produk perangkat lunak yang sesuai dengan kebutuhan user (Satzinger, J. W., Jackson, R. B., Burd, n.d.).

Diharapkan dengan adanya suatu sistem informasi dapat menangani permasalahan yang ada di perusahaan tersebut. Sistem adalah setiap sesuatu terdiri dari obyek-obyek, atau unsur-unsur, atau komponen-komponen yang bertata kaitan dan bertata hubungan satu sama lain, sedemikian rupa sehingga unsur-unsur tersebut merupakan satu kesatuan pemrosesan atau pengolahan yang tertentu. (Prasojo, 2011)

Aplikasi keluar masuk barang vaksin ini dapat memudahkan pekerjaan Admin perusahaan dalam melaksanakan pembuatan laporan dan dapat memudahkan dalam hal pengontrolan data vaksin yang keluar dan masuk pada PT. Dharma Bandar Mandala.

\section{METODE PENELITIAN}

Metode penelitian kualitatif digunakan peneliti dalam menyelesaikan permasalahan yang ada di PT. Dharma Bandar Mandala, dimana peneliti sebagai instrumen, teknik pengumpulan data dan analisis yang bersifat kualitatif lebih menekankan pada makna. Metode penelitian kualitatif ini bertujuan untuk menganalisis dan mendeskripsikan fenomena atau objek penelitian melalui aktivitas sosial, sikap dan persepsi orang secara individu atau kelompok (Sugiyono, 2016). Dengan metode kualitatif ini peneliti berkomunikasi dengan Kepala Operasional mengenai keluar masuk nya barang vaksin sehingga peneliti dapat merancangan suatu aplikasi yang sesuai dengan kebutuhan dari PT. Dharma Bandar Mandala (Putra, 2011).

\section{HASIL DAN PEMBAHASAN}

\section{Analisa Permasalahan}

Analisis permasalahan yang dapat penulis simpulkan dari hasil penelitian yang dilakukan di PT Dharma Bandar Mandala adalah bahwa, perusahaan ini termasuk salah satu perusahaan yang belum memiliki sistem vaksin masuk dan vaksin keluar berbasis komputerisasi, sehingga dirasakan masih sangat membutuhkan sistem yang mampu dan memberikan kemudahan bagi bagianbagian yang terkait dalam sistem vaksin masuk dan vaksin keluar.

Ada beberapa permasalahan yang dimiliki oleh pihak perusahaan antara lain, laporan vaksin masuk dan laporan vaksin keluar yang masih dilakukan pencatatan secara manual dengan menggunakan berkas sehingga menyulitkan petugas ketika akan melakukan pencarian data ataupun pengarsipan data. Pencatatan data vaksin masuk dan vaksin keluar yang berjalan belum maksimal karena penggunaan berkas sebagai sarana pencatatan vaksin masuk dan vaksin keluar. Dalam proses pengarsipan vaksin masuk dan vaksin keluar perusahaan masih menggunakan pencatatan buku besar sehingga petugas sering kesulitan mencari data satu persatu (Setiyanto, Nurmaesah, \& Rahayu, 2019).

\section{Alternatif Penyelesaian Masalah}

Alternatif penyelesaian masalah yang penulis usulkan adalah dengan membuat sebuah aplikasi vaksin masuk dan vaksin keluar dengan menggunakan bahasa pemrogram java dan 
penyimpanan data-data pada media database MYSQL. Dengan adanya aplikasi ini diharapkan mampu memberikan kontribusi yang positif bagi kemajuan dalam pengolahan data-data vaksin masuk dan vaksin keluar. Proses pencarian data tidak lagi membutuhkan waktu yang lama karena data-data perusahaan yang ada sudah tersimpan pada media database. Dengan usulan ini diharapkan permasalah pada pengolahan data-data vaksin masuk dan vaksin keluar perusahaan dapat tertangani dengan cepat dan akurat.

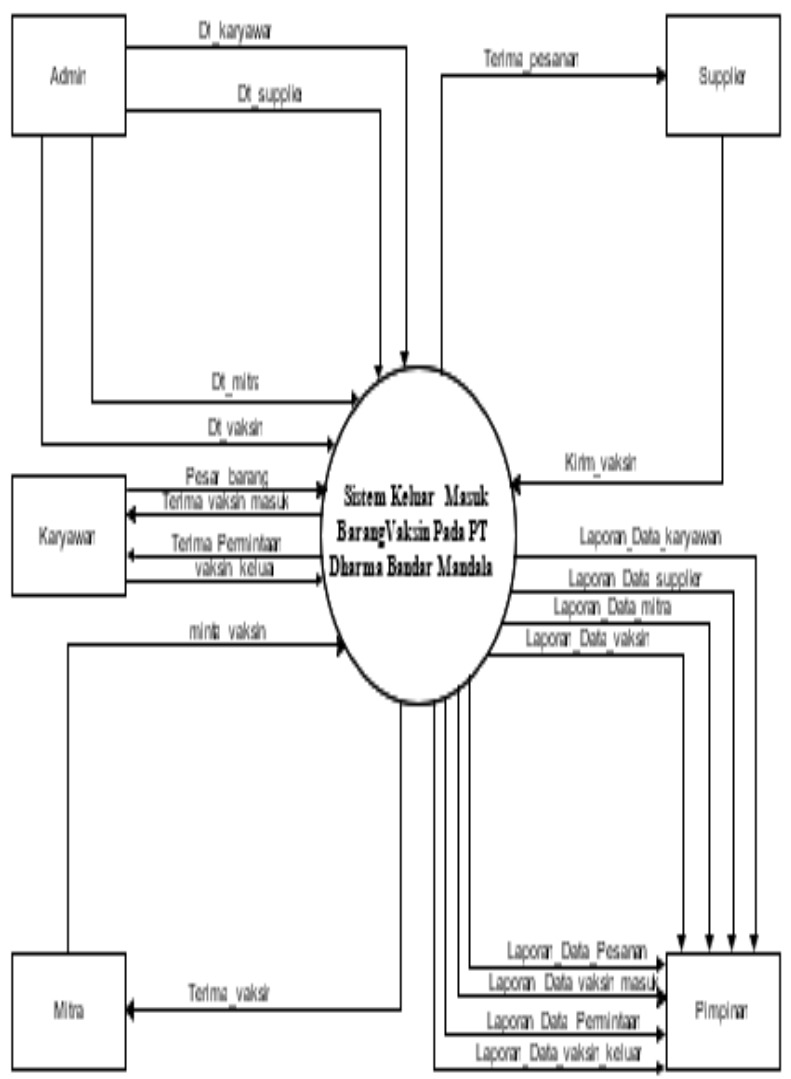

Gambar 1. Diagram Konteks

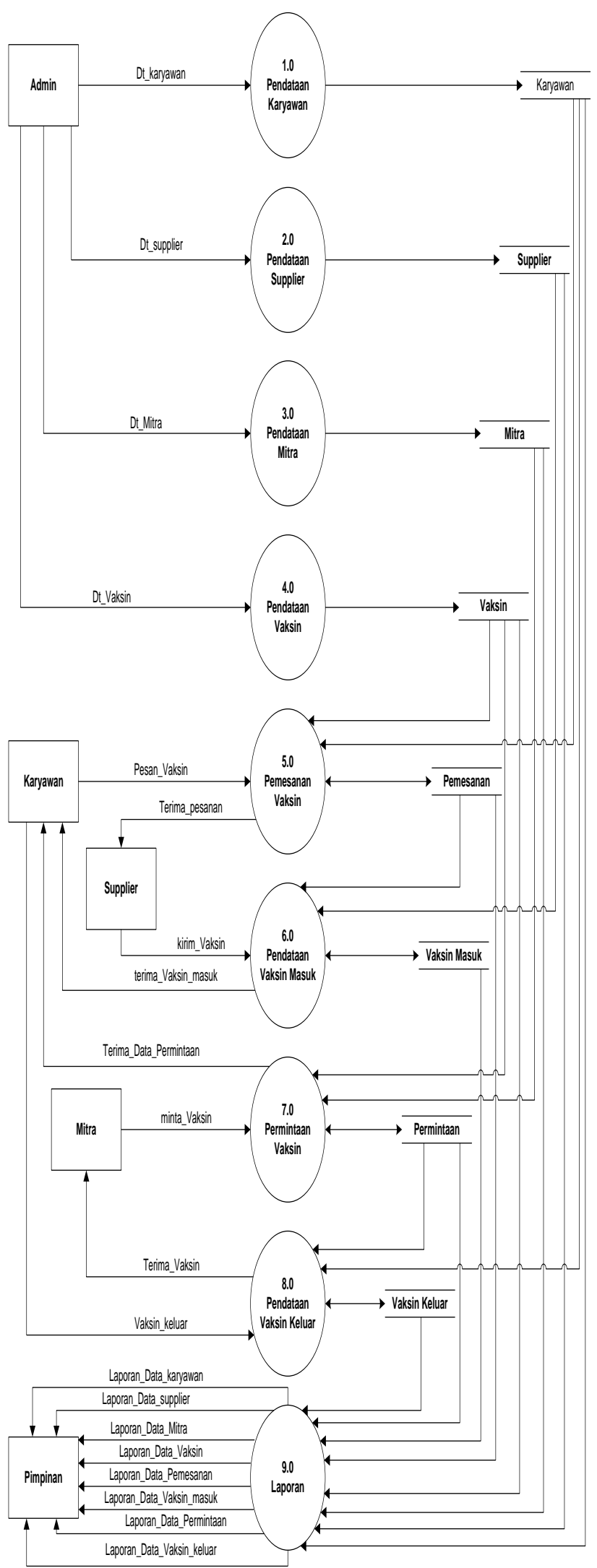

Gambar 2. Diagram Nol

697 | Membangun Aplikasi Keluar Masuk Barang Vaksin pada PT. Dharma Bandar Mandala 


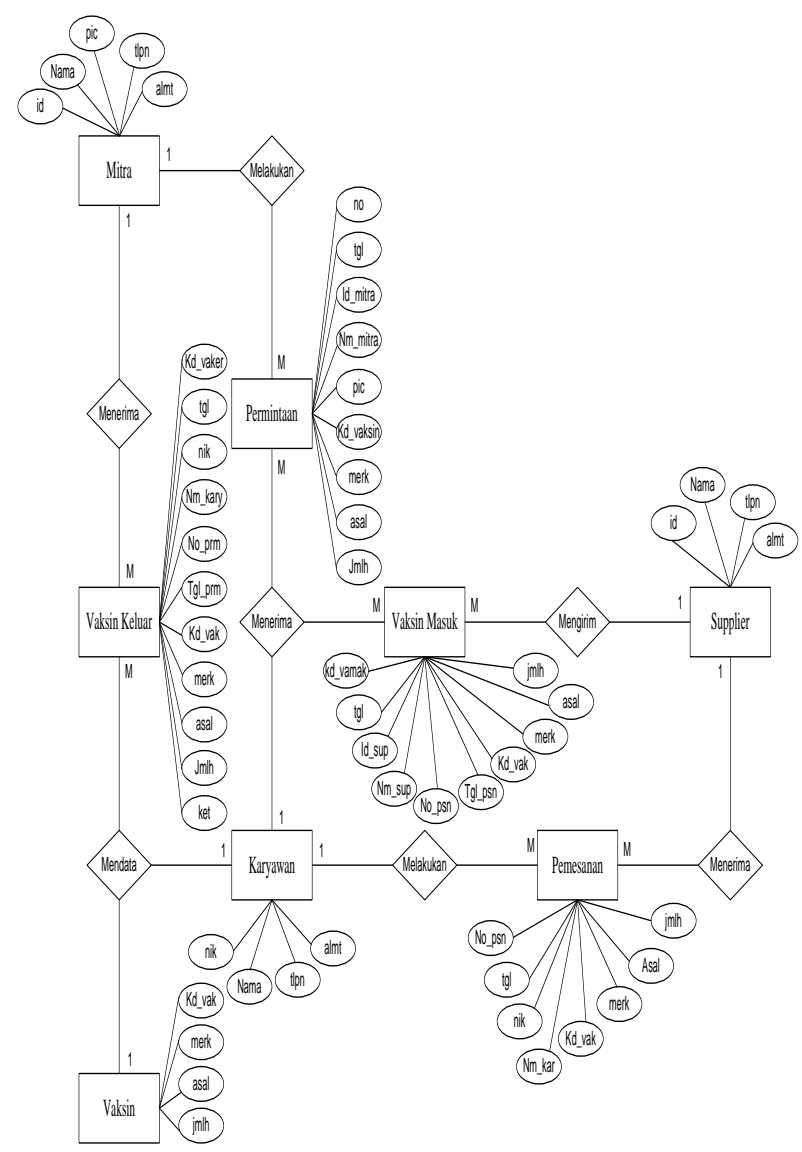

Gambar 3. ERD (Entity Relationship Diagram)

Berikut adalah tampilan layar dan hasil pengujian pada software program yang telah di buat dengan bahasa pemrograman Java.

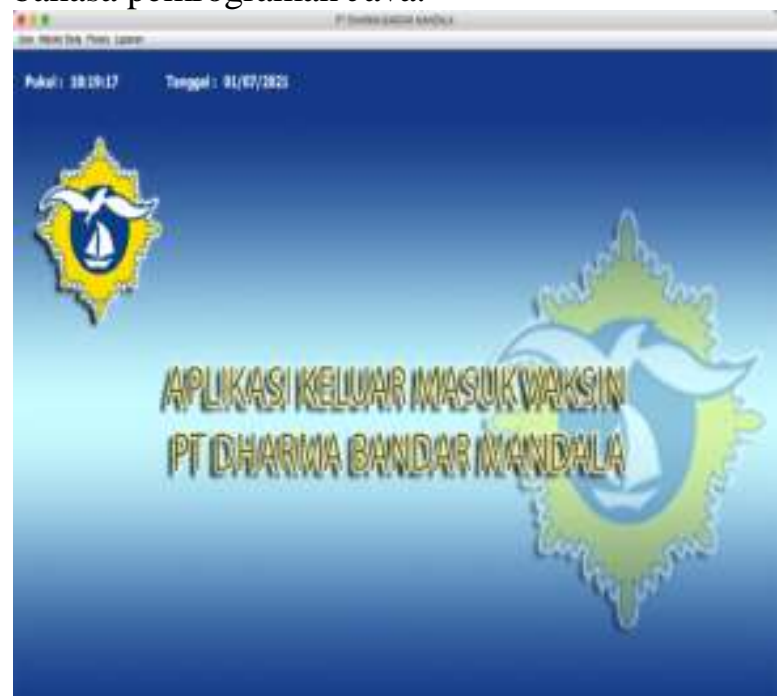

Gambar 4. Form Menu Utama

Tampilan menu utama ini terdapat beberapa icon menu yang akan menampilkan form-form transaksi diantaranya adalah data utama, master data dan laporan.

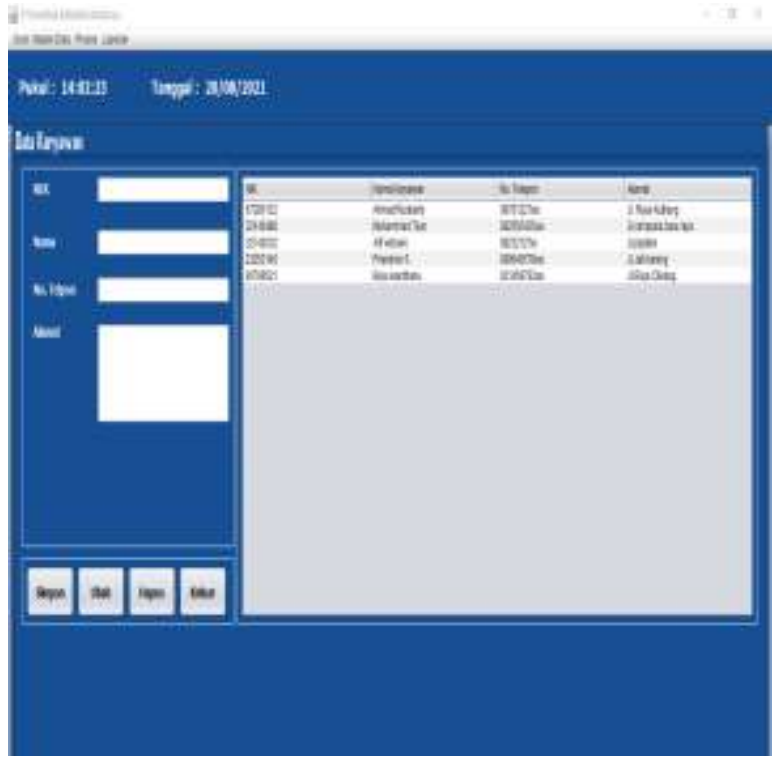

Gambar 5. Form Data Karyawan

Tampilan form data karyawan ini, user dapat melakukan penambahan data karyawan, mengubah, dan menghapus data karyawan. Masukkan nik untuk melakukan pengecekan datadata yang sudah tersimpan. Lakukan pengisian apabila akan dilakukan penambahan data dan tekan tombol (simpan) untuk menyimpan data, untuk memperbarui data tombol (edit), dan untuk menghapus data klik tombol (hapus). Pilih tombol (keluar) apabila ingin menutup form data karyawan dan kembali ke tampilan menu utama.

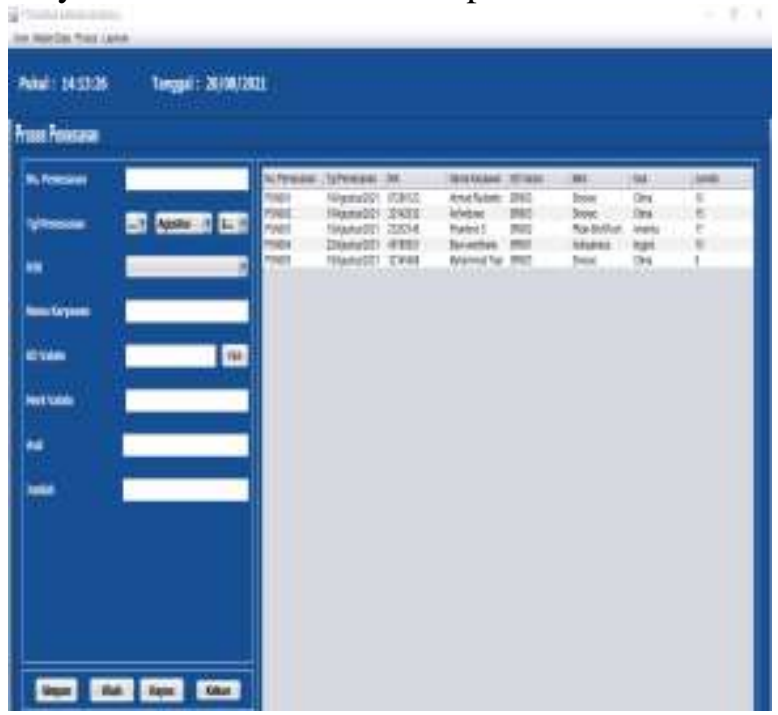

Gambar 6. Form Data Pemesanan 
Tampilan form data pemesanan ini, user dapat melakukan penambahan data pemesanan, mengubah, dan menghapus data pemesanan untuk melakukan pengecekan data-data yang sudah tersimpan. Lakukan pengisian apabila akan dilakukan penambahan data dan tekan tombol (simpan) untuk menyimpan data, untuk memperbarui data tombol (edit), dan untuk menghapus data klik tombol (hapus). Pilih tombol (keluar) apabila ingin menutup form data pemesanan dan kembali ke tampilan menu utama.

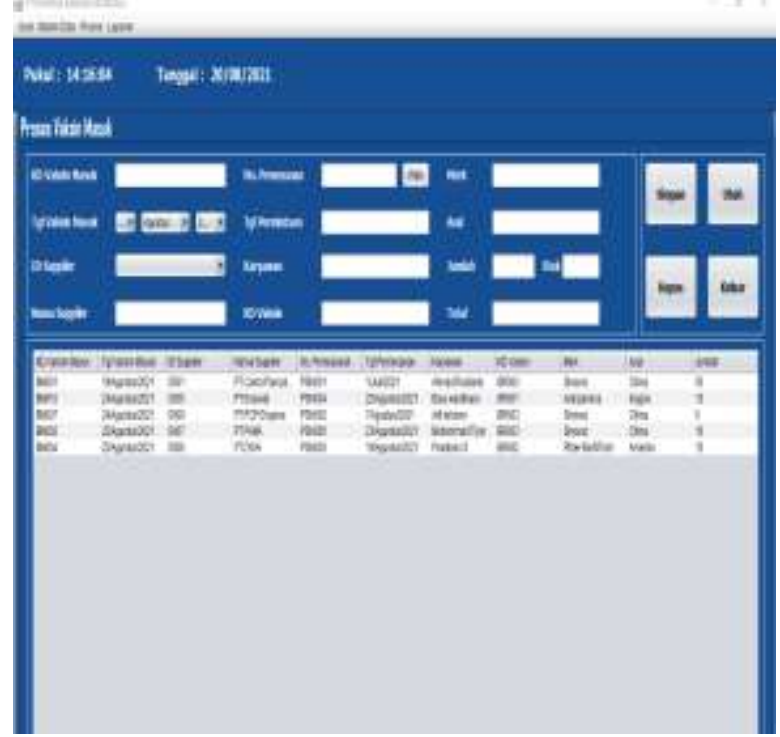

Gambar 7. Data Form Data Vaksin Masuk

Tampilan form data vaksin masuk ini, user dapat melakukan penambahan data vaksin masuk, mengubah, dan menghapus data vaksin masuk untuk melakukan pengecekan data-data yang sudah tersimpan. Lakukan pengisian apabila akan dilakukan penambahan data dan tekan tombol (simpan) untuk menyimpan data, untuk memperbarui data tombol (edit), dan untuk menghapus data klik tombol (hapus). Pilih tombol (keluar) apabila ingin menutup form data vaksin masuk dan kembali ke tampilan menu utama.

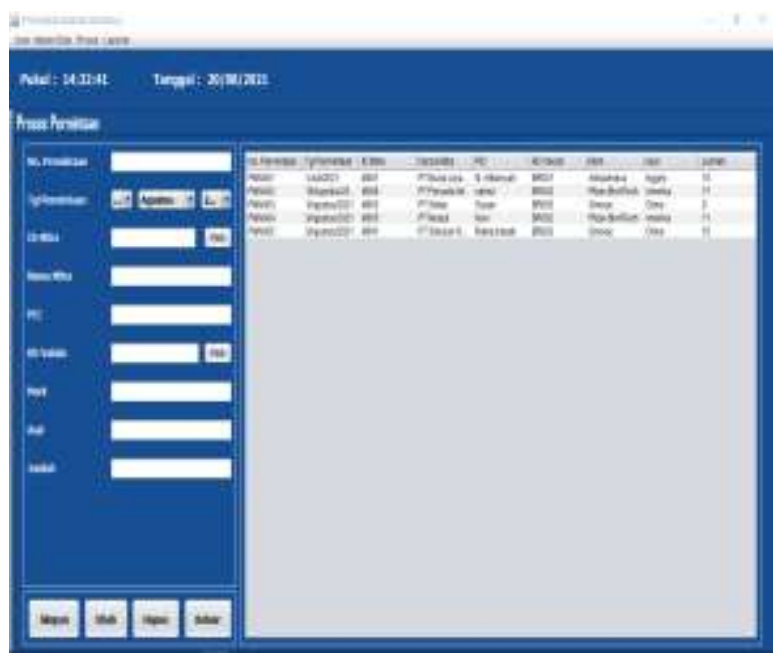

Gambar 8. Form Data Permintaan

Tampilan form data permintaan ini, user dapat melakukan penambahan data permintaan, mengubah, dan menghapus data permintaan untuk melakukan pengecekan data-data yang sudah tersimpan. Lakukan pengisian apabila akan dilakukan penambahan data dan tekan tombol (simpan) untuk menyimpan data, untuk memperbarui data tombol (edit), dan untuk menghapus data klik tombol (hapus). Pilih tombol (keluar) apabila ingin menutup form data permintaan dan kembali ke tampilan menu utama.

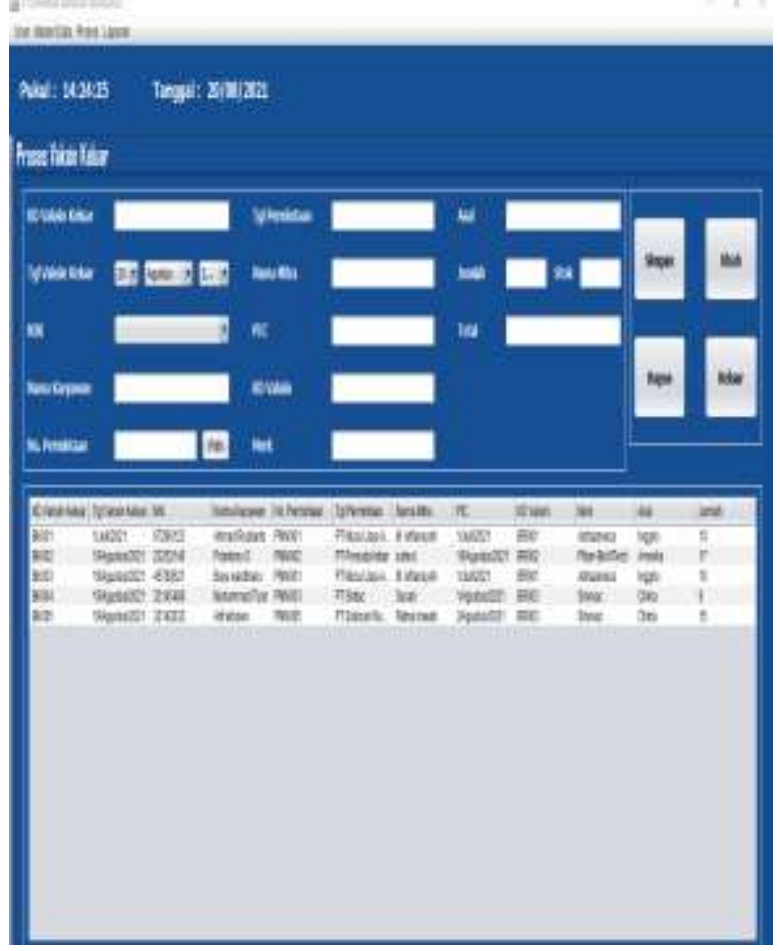

Gambar 9. Form Data Vaksin Keluar 
Tampilan form data vaksin keluar ini, user dapat melakukan penambahan data vaksin keluar, mengubah, dan menghapus data vaksin keluar untuk melakukan pengecekan data-data yang sudah tersimpan. Lakukan pengisian apabila akan dilakukan penambahan data dan tekan tombol (simpan) untuk menyimpan data, untuk memperbarui data tombol (edit), dan untuk menghapus data klik tombol (hapus). Pilih tombol (keluar) apabila ingin menutup form data vaksin keluar dan kembali ke tampilan menu utama.

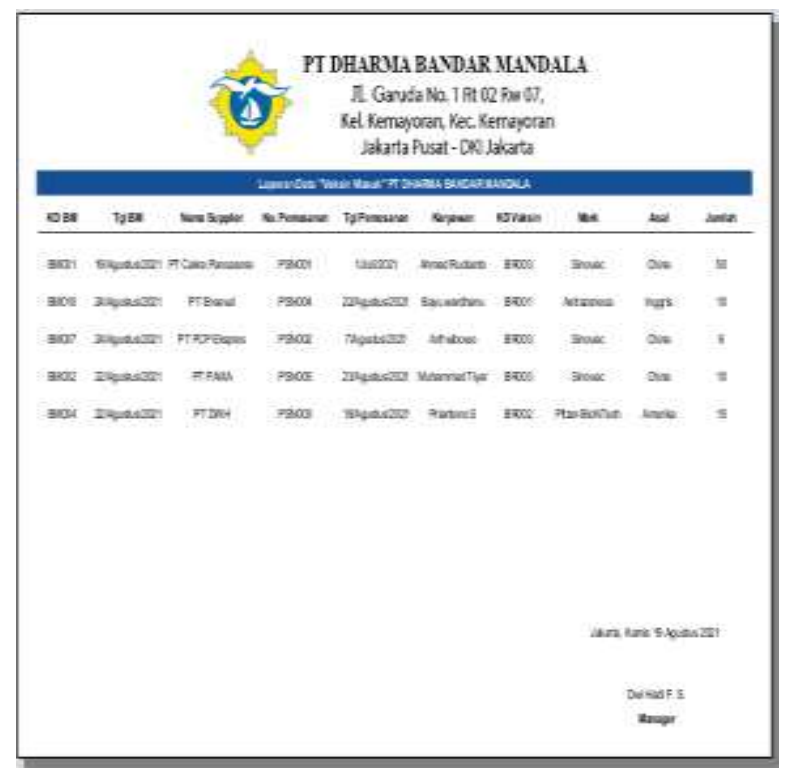

Gambar 10. Laporan Data Vaksin Masuk

Tampilan laporan vaksin masuk ini berisi datadata yang ada pada tabel vaksin masuk. Laporan ini muncul ketika user mengklik tombol laporan data vaksin masuk pada tampilan menu utama.

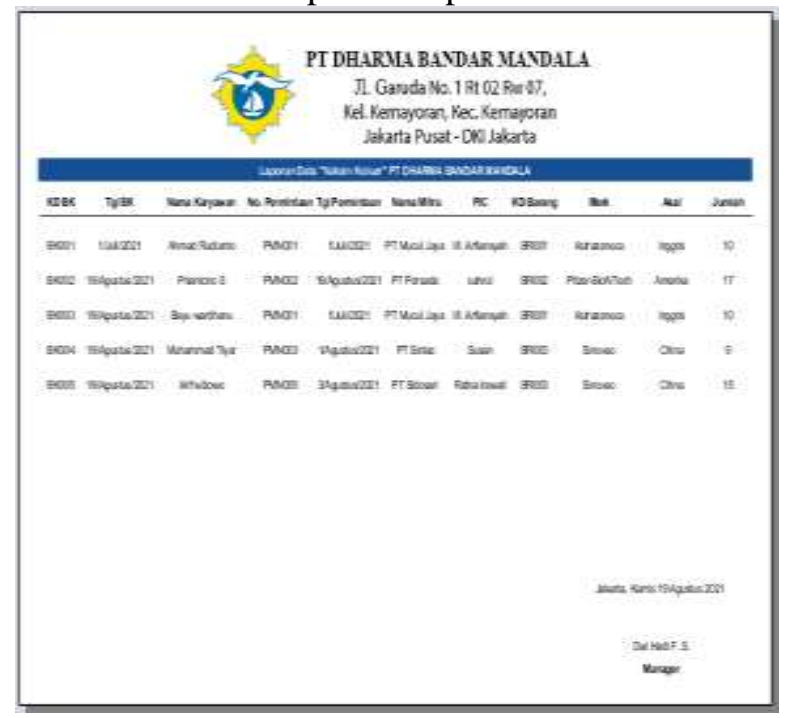

Gambar 11. Laporan Data Pembelian
Tampilan laporan vaksin keluar ini berisi datadata yang ada pada tabel vaksin keluar. Laporan ini muncul ketika user mengklik tombol laporan data vaksin keluar pada tampilan menu utama.

\section{SIMPULAN DAN SARAN}

Hasil implementasi sistem yang telah dibuat dirasakan lebih efektif. Penyimpanan data-data pada media database akan mempercepat dalam pencarian data. Pada proses pembuatan laporan aplikasi ini akan sangat membantu dalam pengolahan data-data yang maksimal dan efisien dalam pembuatan pengolahan data vaksin masuk dan vaksin keluar.

Sarannya adalah keamanan sistem perlu dijaga dengan cara mempercayakan kepada karyawan yang dapat bertanggung jawab.

\section{DAFTAR PUSTAKA}

Mahmudah, S., Widiastuti, L., \& Ernawati, S. (2019). Sistem Informasi Manajemen Pengarsipan Surat Masuk Dan Surat Keluar (Studi Kasus: Ma Darul Ihya Bogor). JURNAL MEDIA INFORMATIKA BUDIDARMA. https://doi.org/10.30865/mib.v3i3.1215

Maulana Syaban, izky, \& Bunyamin, H. (2016). Pengembangan Sistem Informasi Pengelolaan Surat Masuk dan Surat Keluar Berbasis Web di Dinas Sosial Tenaga Kerja dan Transmigrasi Kabupaten Garut Menggunakan Framework PHP. Jurnal Algoritma.

https://doi.org/10.33364/algoritma/v.122.301

Prasojo, M. (2011). Pengantar Sistem Informasi Manajemen bandung: CV. Remadja Karya.

Putra, N. (2011). Research and Development, Penelitian dan Pengembangan: Suatu Pengantar. Jakarta: PT Raja Grafindo Persada.

Rustamin, Z., \& Dewi, A. P. (2016). Sistem Pengarsipan Surat Masuk Dan Surat Keluar Pada Kantor Sekretariat DPRD Provinsi Sulawesi Tenggara Menggunakan Borland Delphi 7. Sistem Informasi Dan Teknik Komputer.

Satzinger, J. W., Jackson, R. B., Burd, S. D. (n.d.). System Analysis and Design in A Changing 
World. USA: Cengage Learning.

Setiyanto, R., Nurmaesah, N., \& Rahayu, N. S. A.

(2019). Perancangan Sistem Informasi

Persediaan Barang Studi Kasus di Vahncollections. Jurnal Sisfotek Global, 9(1), 137-142.

Sugiyono. (2016). Metode Penelitian Kuantitatif, Kualitatif dan $R \& D$. Bandung: PT Alfabet.

Sutabri, T. (2012). Analisis Sistem Informasi. Yogyakarta: Andi.

Tyoso, J. S. P. (2016). Sistem Informasi Manajemen. Yogyakarta: DeePublish.

Waluyo, edy tekat bronto, Hanafri, M. I., \& Sulaeman. (2019). Perancangan Sistem Informasi Persediaan Barang Pada Gudang Sparepart. Sisfotek Global, 9(1), 13-19. 